\title{
Transpiration difference under high evaporative demand in chickpea (Cicer arietinum L.) may be explained by differences in the water transport pathway in the root cylinder
}

\author{
K Sivasakthi ${ }^{1,2}$, M Tharanya ${ }^{1,2}$, M Zaman-Allah $^{3}$ (D) , J Kholová ${ }^{1}$, T Thirunalasundari $^{2}$ \& V Vadez ${ }^{1,4}$ (iD \\ 1 Crop Physiology Laboratory, International Crops Research Institute for the Semi-Arid Tropics (ICRISAT), Patancheru, Telangana, India \\ 2 Department of Industrial Biotechnology, Bharathidasan University, Tiruchirappalli, Tamilnadu, India \\ 3 International Center for Maize and Wheat Improvement (CIMMYT), Mount Pleasant Harare, Zimbabwe \\ 4 IRD (Institut de Recherche pour le Developpement) - Univ. Montpellier - UMR DIADE, Montpellier cedex 5, France
}

\begin{abstract}
Keywords
Apoplastic pathway; aquaporins; cell-to-cell pathway; drought; hydraulics; roots; water saving.

\section{Correspondence \\ $\checkmark$ Vadez, IRD (Institut de Recherche pour le DIADE, 911 Avenue Agropolis, BP 64501, 34394 Montpellier cedex 5, France. \\ E-mails: Vincent.vadez@ird.fr; \\ v.vadez@cgiar.org} Developpement) - Univ. Montpellier - UMR
\end{abstract}

Editor: S. Pfautsch

Received: 16 April 2020; Accepted: 4 June 2020

doi:10.1111/plb.13147

\section{ABSTRACT}

- Terminal drought substantially reduces chickpea yield. Reducing water use at vegetative stage by reducing transpiration under high vapor pressure deficit (VPD), i.e. under dry/ hot conditions, contributes to drought adaptation. We hypothesized that this trait could relate to differences in a genotype's dependence on root water transport pathways and hydraulics.

- Transpiration rate responses in conservative and profligate chickpea genotypes were evaluated under increasing VPD in the presence/absence of apoplastic and cell-to-cell transport inhibitors.

- Conservative genotypes ICC 4958 and ICC 8058 restricted transpiration under high VPD compared to the profligate genotypes ICC 14799 and ICC 867. Profligate genotypes were more affected by aquaporin inhibition of the cell-to-cell pathway than conservative genotypes, as measured by the root hydraulic conductance and transpiration under high VPD. Aquaporin inhibitor treatment also led to a larger reduction in root hydraulic conductivity in profligate than in conservative genotypes. In contrast, blockage of the apoplastic pathway in roots decreased transpiration more in conservative than in profligate genotypes. Interestingly, conservative genotypes had high early vigour, whereas profligate genotypes had low early vigour.

- In conclusion, profligate genotypes depend more on the cell-to-cell pathway, which might explain their higher root hydraulic conductivity, whereas water-saving by restricting transpiration led to higher dependence on the apoplastic pathway. This opens the possibility to screen for conservative or profligate chickpea phenotypes using inhibitors, itself opening to the search of the genetic basis of these differences.

\section{INTRODUCTION}

Chickpea (Cicer arietinum L.) is the second most important food legume worldwide (FAOSTAT 2013). Chickpea production areas are mainly in arid and semi-arid zones, where end of season drought (terminal drought, i.e. stress in the post-flowering period, and critically at the grain filling stage) is a major constraint. Such constraints reduce yield, typically by more than 50\% (Leport et al., 1999, 2006; Kumar \& Abbo, 2001). Crop adaptation to water limitation is a balance between maximizing water use and ensuring a crop has sufficient water to complete its cycle (Vadez et al., 2013a). One such adaptation involves controlling plant water loss during vegetative growth, even when water is plentiful, by restricting transpiration under high vapor pressure deficit (VPD), i.e. conditions combining high temperature and low relative humidity. Conserving soil moisture for the later grain filling stage is crucial to increase crop yield under terminal water stress (reviewed in Vadez et al., 2013a). A mechanism for reducing transpiration under high VPD has been described for chickpea (Cicer arietinum L.;
Zaman-Allah et al., 2011a) and other species, such as pearl millet (Pennisetum glaucum L.; Kholová et al., 2010), sorghum (Sorghum bicolor L.; Gholipoor et al., 2010), soybean (Glycine $\max ($ L.) Merr; Fletcher et al., 2007; Gilbert et al., 2011), wheat (Schoppach \& Sadok 2012), peanut (Arachis hypogaea L.; Devi et al., 2010), cowpea (Vigma unguiculata L.;Belko et al., 2013) and in maize (Zea mays L.; Yang et al., 2012; Gholipoor et al., 2013). This water conservation strategy has been shown to be directly linked to increased crop production under water-limited conditions (Zaman-allah et al., 2011a; Messina et al., 2013; Vadez et al., 2013b, 2014; Kholová et al., 2014). Reduced extraction of soil water by deeper roots during the vegetative stage is expected to retain more water in the soil profile for extraction at later growth stages, e.g. grain filling, when water becomes scarce. This strategy makes sense for the heavy clay and often deep soils in which chickpea is cultivated in India.

Restriction of transpiration under high VPD might be related to differences in the way in which water is channeled through the plant. It is generally agreed that there are two major sites of resistance to water flow through plant tissues: (i) 
at canopy level, i.e. at the leaf surface where the stomata and cuticle control water flow without restriction through the xylem; and (ii) at the root system level, i.e. through the root cylinder (Steudle, 1994; Steudle \& Peterson, 1998). According to Steudle \& Frensch (1996), a composite model for root water uptake involves three pathways: apoplastic, symplastic (mediated by plasmodesmata) and trans-cellular (mediated through cell and vacuole membranes so that passage of water through the trans-cellular pathway involves crossing two plasma membranes per cell layer). The last two are often aggregated and called the cell-to-cell pathway. The resistance of each pathway differs and the predominance of one path over another may depend on the driving force and on the respective resistance of each pathway (Miyamoto et al., 2001). Water transport in the apoplastic compartment is mainly driven by hydrostatic forces, while the cell-to-cell pathway involves both osmotic and hydrostatic gradients. Hydrostatic forces are caused by negative pressure in the xylem as a consequence of plant transpiration, in which case water is pulled towards the xylem to compensate for these negative pressures. Osmotic forces result from the pumping of solutes in the roots which creates a positive root pressure that contributes to push water into the xylem. Based on evaporative demand from the shoot, the composite transport model would allow for adjustment between the apoplastic and cell-to-cell pathways (Ranathunge et al., 2003, 2005).

It should be noted that the separation between the cell-tocell and apoplastic pathways remains a theoretical representation of water movement in root cylinders, since apoplastic water also needs to go through the cell-to-cell pathway, at least in the endodermis where the Casparian band and suberization block apoplastic water flow. Therefore, what we call the 'apoplastic' pathway in this paper also implies that water may traverse aquaporins at some point. There is numerous evidence that the cell-to-cell pathway involves water transport through aquaporins, a family of major intrinsic proteins (MIP) known for their ability to facilitate water flow (Javot \& Maurel, 2002; Fricke \& Chaumont, 2006; Hachez et al., 2006; Maurel, 2007; Katsuhara et al., 2008). Therefore, the cell-to-cell pathway could be rapidly tuned up or down, depending on plant need. As such, the cell-to-cell pathway offers additional flow control through the activity of aquaporins. However, the extent to which either pathway contributes to root water chanelling in various species, genotypes and in response to environmental pressures, as much as the two pathways can be distinguished, is still not understood. In addition, apoplastic and cell-to-cell water transport pathways may differ in terms of hydraulic conductivity (Steudle, 2000; Javot \& Maurel, 2002; Aroca et al., 2005). Therefore, the relationship of these two pathways with traits controlling plant water use and with possible differences in these traits among genotypes are investigated here. This was tested by either inhibiting aquaporin-mediated water flow in the cell-to-cell pathway using aquaporin inhibitors, or by blocking the water flow in the apoplast using a perfusion technique (Ranathunge et al., 2004) in contrasting chickpea genotypes.

The objective of this study was to test the hypothesis that chickpea genotypes with contrasting transpiration responses to increasing VPD may respond differently to the different water transport pathways in the root cylinder. Therefore this work aimed to: (i) confirm the transpiration response to VPD differences among several genotypes; (ii) compare their cell-to-cell (aquaporin-mediated) and apoplastic water flow by examining the response of transpiration to chemical inhibition of either pathway; and (iii) measure root hydraulic conductivity after aquaporin inhibition.

\section{MATERIAL AND METHODS}

\section{Plant material and growth conditions}

Four chickpea genotypes with contrasting transpiration response to high VPD were selected. The salient features of the selected genotypes are described in Table 1. Two genotypes (ICC 867 and ICC 14799) showed profligate transpiration under high VPD, whereas one (ICC 8058) had conservative transpiration under high VPD (Zaman-allah et al., 2011a). Genotype ICC 4958, a popular drought-tolerant genotype, was also expected to have conservative transpiration under high VPD, as it has low stomatal conductance under high VPD in outdoor experiments (Zamman-Allah et al., 2011b). Other information on these genotypes was obtained from the ICRISAT mini-core collection under terminal drought stress

Table 1. Salient features of the four selected chickpea genotypes (days to $50 \%$ flowering, days to maturity, drought tolerance) with contrasting plant water saving characteristics (profligate and conservative). Data on days to flowering (DF), days to maturity (DM) and drought tolerance are mean of 3 years of field experiments (Krishnamurthy et al., 2010). Data on shoot components (leaf size and total leaf area) were from soil-grown plants during the transpiration assessment in Experiment 1. Shoot biomass and leaf area index are from soil-grown plants during a Leasyscan phenotyping experiment (Sivasakthi et al. - unpublished data). Root components were from hydroponically grown plants in the root hydraulic conductivity experiments (2-4).

\begin{tabular}{|c|c|c|c|c|}
\hline $\begin{array}{l}\text { trait } \\
\text { description }\end{array}$ & $\begin{array}{l}\text { ICC } 867 \\
\text { (Profligate) }\end{array}$ & $\begin{array}{l}\text { ICC } 14799 \\
\text { (Profligate) }\end{array}$ & $\begin{array}{l}\text { ICC } 4958 \\
\text { (Conservative) }\end{array}$ & $\begin{array}{l}\text { ICC } 8058 \\
\text { (Conservative) }\end{array}$ \\
\hline \multicolumn{5}{|c|}{ Shoot components } \\
\hline Leaf size & Smaller & Smaller & Larger & Larger \\
\hline $\begin{array}{l}\text { Total leaf } \\
\text { area } \\
\left(\mathrm{cm}^{2} \text { plant }^{-1}\right)\end{array}$ & 85 & 105 & 180 & 150 \\
\hline $\begin{array}{l}\text { Shoot } \\
\text { biomass } \\
\left(\text { g plant }^{-1}\right)\end{array}$ & 2.63 & 2.60 & 3.89 & 3.51 \\
\hline $\begin{array}{l}\text { Leaf area } \\
\text { index (LAI) }\end{array}$ & 0.52 & 0.51 & 0.71 & 0.66 \\
\hline \multicolumn{5}{|c|}{ Root components } \\
\hline $\begin{array}{l}\text { Root surface } \\
\text { area }\left(\mathrm{cm}^{2}\right)\end{array}$ & 51 & 55 & 82 & 71 \\
\hline $\begin{array}{l}\text { Root volume } \\
\left(\mathrm{cm}^{3}\right)\end{array}$ & 1.9 & 2 & 3 & 2.6 \\
\hline $\begin{array}{l}\text { Root dry } \\
\text { weight (g) }\end{array}$ & 0.09 & 0.12 & 0.14 & 0.17 \\
\hline $\begin{array}{l}\text { Days to } 50 \% \\
\text { flowering } \\
\text { (DF) }\end{array}$ & 44 & 48 & 37 & 47 \\
\hline $\begin{array}{l}\text { Days to } \\
\text { maturity } \\
\text { (DM) }\end{array}$ & 88 & 90 & 82 & 95.6 \\
\hline $\begin{array}{l}\text { Drought } \\
\text { tolerance }\end{array}$ & $\begin{array}{l}\text { High } \\
\text { tolerance }\end{array}$ & Tolerant & $\begin{array}{l}\text { Moderate } \\
\text { tolerance }\end{array}$ & Sensitive \\
\hline
\end{tabular}


conditions in the field for 3 years (Krishnamurthy et al., 2010)

(Table 1).

Plants were grown in a glasshouse, either in pots filled with soil or in hydroponic conditions (see below for details). Day/ night temperatures and relative humidity $(\mathrm{RH}, \%)$ were, on average, $28 / 22{ }^{\circ} \mathrm{C}$ and $70 / 90 \%$, respectively, under natural a photoperiod. Details of this experiment are reported in Table 2.

\section{Transpiration response to increasing VPD}

Experiment 1 was carried out to test and confirm whole plant transpiration response to increasing VPD of the above genotypes 32 day after sowing (DAS), when plants were still at the vegetative stage. Plants were grown in plastic pots $(3 \mathrm{l} ; 19.0-\mathrm{cm}$ diameter $\times 15.24-\mathrm{cm}$ high) filled with $1.5 \mathrm{~kg}$ of Vertisol, collected from the ICRISAT farm, and fertilized with DAP (diammonium phosphate) at $0.3 \mathrm{~g} \cdot \mathrm{kg}^{-1}$ soil. Each pot received $0.1 \mathrm{~g}$ carbofuran applied to the surface of the soil a day before sowing to prevent soilborne pests. Seeds were treated with thiram (fungicide) to avoid fungal contamination. Three seeds were sown in each pot and a rhizobium inoculum (Strain No: IC 2002) was added to each pot to ensure nodulation. Two weeks after sowing, plants were thinned to one plant per pot. Plants were grown under well-watered conditions for 32 days (vegetative stage).

A plastic sheet was put on top of the soil in each pot and then a $2-\mathrm{cm}$ layer of plastic beads was poured on top of the sheet to limit soil water evaporation. Eight replicate plants were used for each genotype. Plants were moved to the controlled environment growth chamber (Conviron-PGW36; Controlled Environments, Winnipeg Manitoba, Canada, http://www.convi ron.com/sites/default/files/PGW36\%20Data\%20Sheet_1.pdf) about $40 \mathrm{~h}$ before assessing plant transpiration response to increasing VPD. The plants were acclimatized for an entire day to growth chamber conditions, i.e. light period (06:30-18:30 h; $1.8 \mathrm{kPa}$, i.e. $31^{\circ} \mathrm{C}, 60 \% \mathrm{RH}, 450 \mu \mathrm{mol} \cdot \mathrm{m}^{-2} \mathrm{~s}^{-1}$ photosynthetic photon flux density) and night time VPD (19:30-05:30 h; $0.9 \mathrm{kPa}$, i.e. $\left.27^{\circ} \mathrm{C}, 75 \% \mathrm{RH}\right)$. The day before the experiment, pots were irrigated and left to drain overnight to reach field

Table 2. Description of experiments, material tested, plant growth system, plant growth location, treatment, plant part investigated and trait measured

\begin{tabular}{|c|c|c|c|c|c|c|c|c|}
\hline exp.no & genotype & experiment & $\begin{array}{l}\text { plant growth } \\
\text { system - } \\
\text { Environment }\end{array}$ & $\begin{array}{l}\text { plants part investigated a trait } \\
\text { measured - Experiment } \\
\text { location }\end{array}$ & $\begin{array}{l}\text { concentration } \\
\text { of inhibitors }\end{array}$ & $\begin{array}{l}\text { no. replicates per } \\
\text { genotype per } \\
\text { treatment }\end{array}$ & $\begin{array}{l}\text { plant age } \\
\text { when } \\
\text { tested }\end{array}$ & $\begin{array}{l}\text { VPD }(\mathrm{kPa}) \\
\text { in } \\
\text { experiment }\end{array}$ \\
\hline 1 & $\begin{array}{l}\text { ICC } \\
14799 \\
\text { ICC } 867 \\
\text { ICC } \\
4958 \\
\text { ICC } \\
8058\end{array}$ & $\begin{array}{l}\text { TR response } \\
\text { to increasing } \\
\text { VPD }\end{array}$ & $\begin{array}{l}\text { Pots with black } \\
\text { soil } \\
\text { (Vertisol) - } \\
\text { glasshouse }\end{array}$ & $\begin{array}{l}\text { whole plant, } \\
\mathrm{TR}\left(\mathrm{mg} \cdot \mathrm{H}_{2} \mathrm{O} \mathrm{cm}^{-2} \mathrm{~min}^{-1}\right) \text { - } \\
\text { growth chamber } \\
\text { growth chamber }\end{array}$ & - & 8 & 30 & $(0.7-4.21)$ \\
\hline 2 & $\begin{array}{l}\text { ICC } \\
14799 \\
\text { ICC } 867 \\
\text { ICC } \\
4958 \\
\text { ICC } \\
8058\end{array}$ & $\begin{array}{c}\text { Aquaporin } \\
\text { inhibition }\end{array}$ & $\begin{array}{l}\text { Hydroponics - } \\
\text { Glasshouse }\end{array}$ & $\begin{array}{l}\text { whole plant, } \\
\text { level of aquaporin inhibition - } \\
\text { Growth chamber }\end{array}$ & $1 \mathrm{mM} \mathrm{H}_{2} \mathrm{O}_{2}$ & $\begin{array}{l}4 \text { control } \\
4 \text { treatment }\end{array}$ & 25 & 3.1 \\
\hline 3 & $\begin{array}{l}\text { ICC } \\
14799 \\
\text { ICC } 867 \\
\text { ICC } \\
4958 \\
\text { ICC } \\
8058\end{array}$ & $\begin{array}{c}\text { Aquaporin } \\
\text { inhibition }\end{array}$ & $\begin{array}{l}\text { Hydroponics - } \\
\text { Glasshouse }\end{array}$ & $\begin{array}{l}\text { whole plant, } \\
\text { level of aquapoein inhibition - } \\
\text { Growth chamber }\end{array}$ & $\begin{array}{l}100 \mu \mathrm{M} \mathrm{HgCl} \\
\text { and } \\
200 \mu \mathrm{M} \mathrm{HgCl}\end{array}$ & $\begin{array}{l}4 \text { control } \\
4 \text { treatment }\end{array}$ & 25 & 3.1 \\
\hline 4 & $\begin{array}{l}\text { ICC } \\
14799 \\
\text { ICC } 867 \\
\text { ICC } \\
4958 \\
\text { ICC } \\
8058\end{array}$ & $\begin{array}{c}\text { Apoplastic } \\
\text { inhibition }\end{array}$ & $\begin{array}{l}\text { Hydroponics - } \\
\text { Glasshouse }\end{array}$ & $\begin{array}{l}\text { whole plant, } \\
\text { level of apoplastic inhibition - } \\
\text { Growth chamber }\end{array}$ & $\begin{array}{l}1 \mathrm{~mm} \mathrm{~K} 4[\mathrm{Fe} \\
\left.(\mathrm{CN})_{6}\right] \\
\text { and } \\
0.5 \mathrm{~mm} \\
\mathrm{CuSO}_{4}\end{array}$ & $\begin{array}{l}8 \text { control } \\
8 \text { treatment }\end{array}$ & 26 & 3.1 \\
\hline 5 & $\begin{array}{l}\text { ICC } \\
14799 \\
\text { ICC } 867 \\
\text { ICC } \\
4958 \\
\text { ICC } \\
8058\end{array}$ & $\begin{array}{l}\text { Root hydraulic } \\
\text { conductivity } \\
\text { after } \\
\text { aquaporin } \\
\text { inhibition }\end{array}$ & $\begin{array}{l}\text { Hydroponics - } \\
\text { Glasshouse } \\
\text { environment }\end{array}$ & $\begin{array}{l}\text { De-topped roots, Root } \\
\text { hydraulic conductivity } \\
\left(\mathrm{mg} \cdot \mathrm{H}_{2} \mathrm{O} \mathrm{cm} \mathrm{cm}^{-2} \mathrm{~min}^{-1} \mathrm{MPa}^{-1}\right) \\
\text { - Glasshouse }\end{array}$ & $100 \mu \mathrm{M} \mathrm{HgCl} 2$ & $\begin{array}{l}8 \text { control } \\
8 \text { treatment }\end{array}$ & 23 & $1-2.5$ \\
\hline
\end{tabular}


capacity. Pots contained 300-350 ml water available for plant transpiration, which was in excess of daily plant transpiration so that no water stress was expected during the experiment. On the day of the experiment, VPD was gradually increased (from $0.9 \mathrm{kPa}$ to $4.21 \mathrm{kPa}$; Table S1) at 60-min intervals during seven consecutive hours (08:00-15:00 h). Within each VPD level, plants were weighed gravimetrically every $60 \mathrm{~min}$ using $0.01 \mathrm{~g}$ precision scales (KERN 3600-2N; Kern \& Sohn, Balingen, Germany), which took about $10 \mathrm{~min}$. During this time, the VPD was increased to the next level. A data logger for air temperature and relative humidity (Lascar Electronics, UK) was positioned within the plant canopy in the growth chamber. Increases in VPD were achieved by simultaneously increasing the temperature (from 27 to $37^{\circ} \mathrm{C}$ ) and decreasing the relative humidity (from 75 to $33 \%$ ), mimicking natural conditions outdoors, and within ranges that the crop faces under natural conditions (see Table S1). Plants were harvested at the end of the transpiration measurement to measure leaf area (LI-3100C area meter; LI-COR Biosciences, USA). The individual plant transpiration rates (TR) were obtained by dividing transpiration values by leaf area.

Transpiration response to aquaporin inhibition of whole plants using $\mathrm{H}_{2} \mathrm{O}_{2}$ and $\mathrm{HgCl}_{2}$

Experiments 2 and 3 were carried out to test the transpiration response to a set of inhibitors of the cell-to-cell or apoplastic pathway and investigate plant hydraulic characteristics. Plants were grown in a hydroponic system installed in a glasshouse (climate conditions are described above). Seeds were treated and sown in sand wetted with nutrient solution. Rhizobium inoculum (Strain No: IC 2002) was added to ensure nodulation. A week later, seedlings were transferred to $250 \mathrm{ml}$ Erlenmeyer conical flasks containing modified Hoagland nutrient solution. The composition of the solution was $1 \mathrm{mM} \mathrm{MgSO}_{4}$, $0.92 \mathrm{~mm}_{2} \mathrm{KO}_{4}, \quad 0.75 \mathrm{~mm} \quad \mathrm{CaCl}_{2} .2 \mathrm{H}_{2} \mathrm{O}, 0.25 \mathrm{~mm} \quad \mathrm{KH}_{2} \mathrm{PO}_{4}$, $0.04 \mathrm{~mm}$ Fe-EDTA, $5 \mathrm{~mm}$ urea and micronutrients $(2.4 \mu \mathrm{M}$ $\mathrm{H}_{3} \mathrm{BO}_{3}, 0.9 \mu \mathrm{M} \mathrm{MnSO}, 0.6 \mu \mathrm{M} \mathrm{ZnSO}_{4}, 0.62 \mu \mathrm{M} \mathrm{CuSO}_{4}, 0.6 \mu \mathrm{M}$ $\mathrm{Na}_{2} \mathrm{MoO}_{4}$ ). The $\mathrm{pH}$ of the nutrient solution was adjusted between 6.0 and 6.2. Seedlings were passed carefully through the hole of a rubber stopper that fitted tightly to the flask aperture and the hypocotyle was fixed with cotton to prevent the seedling from slipping through. The glass flasks were covered with two layers of paint: first a black layer to ensure darkness in the rooting medium and prevent algal growth; then a layer of white paint to reflect excess sunlight and prevent heating of the flask. Aeration was continuously supplied to roots via a spaghetti tube distribution system with a flow rate above $500 \mathrm{ml} \cdot \mathrm{air} \cdot \mathrm{min}^{-1}$. Water was replaced daily to compensate for any water loss and nutrient solution in the flasks was changed once every 3 days.

To inhibit aquaporin-mediated water flow, aquaporin inhibitors $\left(\mathrm{HgCl}_{2}\right.$ and $\left.\mathrm{H}_{2} \mathrm{O}_{2}\right)$ have been used in several reports $\left(\mathrm{HgCl}_{2}\right.$ : Sadok \& Sinclair, 2010; Devi et al., 2012, 2016; $\mathrm{H}_{2} \mathrm{O}_{2}$ : Henzler et al., 2004; Ye \& Steudle, 2006). Mercury ( $\mathrm{Hg}^{+}$ions) reacts with the sulphohydryl group of cysteine residues within the aquaporin through covalent modifications that change the conformation of the protein leading to inhibition of water transport (Niemietz \& Tyerman, 2002). Hydrogen peroxide is involved in oxidative gating of hydroxyl radicals, resulting in chemical modification of aquiporins, a mechanism reported in maize and chara plants (Henzler et al., 2004; Ye \& Steudle, 2006). In addition, $\mathrm{H}_{2} \mathrm{O}_{2}$ regulates the gating of aquaporins through phosphorylation/dephosphorylation (Boursiac et al., 2008). In experiments 2 and 3 (Table 2), following earlier work (Tharanya et al., 2018), 28-day-old (vegetative stage) hydroponically grown plants were transfered to a growth chamber about $40 \mathrm{~h}$ before the experiment to allow acclimation. After acclimation $\left(1.8 \mathrm{kPa}, \quad\right.$ i.e. $\quad 31^{\circ} \mathrm{C}$ and $60 \% \quad \mathrm{RH}$, $450 \mu \mathrm{mol} \cdot \mathrm{m}^{-2} \mathrm{~s}^{-1}$; see below for further details) for 1 day, plant transpiration was measured over a 7 -h period, starting at 08:00 h under a constant and relatively high VPD $(3.1 \mathrm{kPa}$; i.e. $\left.35^{\circ} \mathrm{C}, 45 \% \mathrm{RH}, 450 \mu \mathrm{mol} \cdot \mathrm{m}^{-2} \mathrm{~s}^{-1}\right)$. Transpiration was measured automatically with $0.01 \mathrm{~g}$ precision scales every $10 \mathrm{~min}$. Transpiration of each plant was measured for 3-4 h without any treatment and then the response of transpiration to aquaporin inhibitor treatments was tested by exposing whole plant roots to $1 \mathrm{~mm} \mathrm{H}_{2} \mathrm{O}_{2}$ applied to the nutrient solution. Transpiration was recorded for $4 \mathrm{~h}$ following this treatment. For each genotype, four untreated (control) and four $\mathrm{H}_{2} \mathrm{O}_{2}$-treated plants were analysed. The same protocol was applied to test the transpiration response to two $\mathrm{HgCl}_{2}$ treatments (100 or $200 \mu \mathrm{M}$ $\mathrm{HgCl}_{2}$; Experiment 3).

After treating plants with the aquaporin inhibitor $(1 \mathrm{~mm}$ $\mathrm{H}_{2} \mathrm{O}_{2}$ ), we tested whether differences in transpiration response to cell-to-cell pathway inhibition could be proxied using canopy temperature measurements. Thermal images (infrared, IR) were taken $2 \mathrm{~h}$ after treatment with $\mathrm{H}_{2} \mathrm{O}_{2}$, using an IR FlexCam S (Infrared Solutions, Plymouth, MN, USA) with a sensitivity of $0.09{ }^{\circ} \mathrm{C}$ and accuracy of $\pm 2 \%$. Images were taken from three plants for each genotype and treatment. SmartView 2.1.0.10 software (Fluke Thermography Everett, WA, USA) was used for analysis of the thermal images and estimation of canopy temperatures.

\section{Transpiration response to apoplast inhibition using precipitates of $\mathrm{CuSO}_{4}$}

Experiment 4 (Table 2) was carried out to test transpiration response to an inhibitor of the apoplastic pathway and investigate plant hydraulic characteristics in 28-day-old hydroponically-grown plants. The apoplastic blockage consisted in exposing plant roots to insoluble salts to block the apoplastic pathway. This consisted in first treating roots with a solution of $1 \mathrm{mM} \mathrm{K}_{4}\left[\mathrm{Fe}(\mathrm{CN})_{6}\right]$, before changing the solution after $1 \mathrm{~h}$ and treating the roots with a solution of $0.5 \mathrm{~mm} \mathrm{CuSO}_{4}$. The reaction between $\mathrm{CuSO}_{4}$ and $\mathrm{K}_{4}\left[\mathrm{Fe}(\mathrm{CN})_{6}\right]$ produced rustybrown, insoluble crystals (precipitates) of $\mathrm{Cu}_{2}\left[\mathrm{Fe}(\mathrm{CN})_{6}\right]$ or $\mathrm{Cu}$ [CuFe $\left.(\mathrm{CN})_{6}\right]$ (Fig. 4D), which obstructed the apoplast lumen (Daniels et al., 1994). Different combinations of exposure duration to $\mathrm{K}_{4}\left[\mathrm{Fe}(\mathrm{CN})_{6}\right](1 \mathrm{~mm})$ were initially tested to determine the optimum time for development of insoluble crystals to significantly restrict the apoplastic pathway. The standardized concentration was $1 \mathrm{~mm} \mathrm{~K}_{4}\left[\mathrm{Fe}(\mathrm{CN})_{6}\right]$ and $0.5 \mathrm{~mm} \mathrm{CuSO}_{4}$. Transpiration was measured over $1 \mathrm{~h}$ without any treatment, followed by $3 \mathrm{~h}$ of transpiration measurement in the presence of $1 \mathrm{mM}_{4}\left[\mathrm{Fe}(\mathrm{CN})_{6}\right]$, and finally $3 \mathrm{~h}$ transpiration measurements following addition of $0.5 \mathrm{~mm} \mathrm{CuSO}_{4}$. A $1 \mathrm{~mm} \mathrm{~K}_{4}[\mathrm{Fe}$ $(\mathrm{CN})_{6}$ ] treatment was used as control, as this had no effect on transpiration (Tharanya et al., 2018). Eight replicate plants per genotype and treatment combination were used. Finally, root samples were collected around $30 \mathrm{~mm}$ from the apex and 

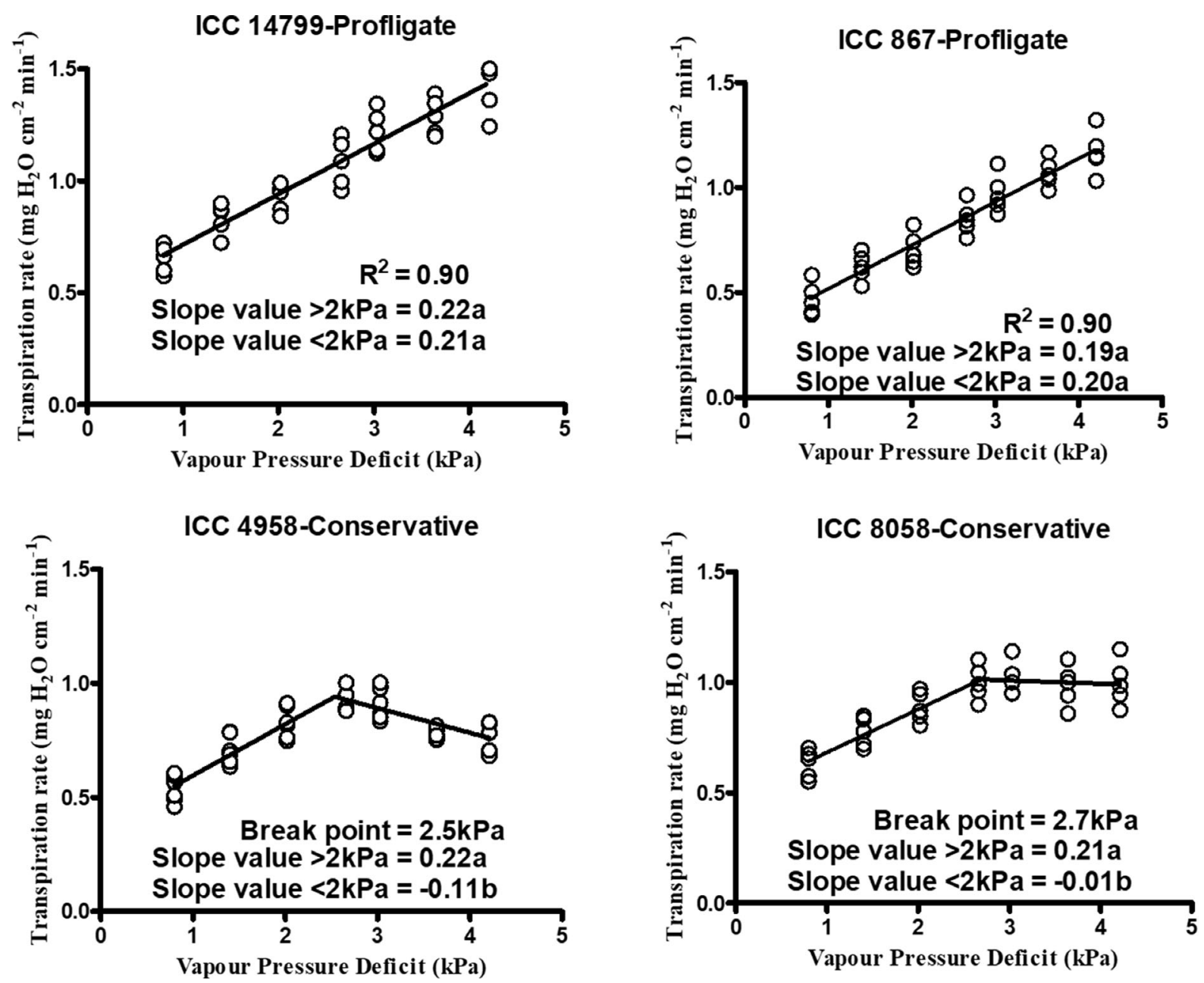

Fig. 1. Response of transpiration (mg. $\mathrm{H}_{2} \mathrm{O} \cdot \mathrm{cm}^{-2} \mathrm{~min}^{-1}$ ) to increasing VPD in four chickpea genotypes [ICC 867 and ICC 14799 (profligate); ICC 4958 and ICC 8058 (conservative)]. Plants were grown in black soil (Vertisol) and tested at vegetative stage (32 days old). Each data point represents an individual plant response to VPD. Mean slope values ( $>2 \mathrm{kPa}$ and $<2 \mathrm{kPa}$ ) followed by different letters indicate significant differences using Tukey's test. $* * * P<0.001, \mathrm{~ns}$ no significant difference in slope $>2 \mathrm{kPa}$ and $<2 \mathrm{kPa}$. See also Table 3 for details.

stained with $0.05 \%$ Toluidine blue at room temperature for 2 min. Free-hand root cross-sections were examined under a light microscope and photographed using a digital camera to confirm the presence of nanoparticles in the root cortex and especially in the root apoplast.

Hydraulic conductivity of detached roots in response to $100 \mu \mathrm{M} \mathrm{HgCl} 2$ treatment

In experiment 5 (Table 2), hydroponically-grown plants were used to measure root hydraulic conductivity in a pressure chamber (PMS instruments, Corvallis, OR, USA) using a protocol similar to that used for barley (Tazawa et al., 1997), tomato (Maggio \& Joly, 1995), wheat (Zhang and Tyerman, 1999) and pearl millet (Tharanya et al., 2017). This measurement was done under glasshouse conditions in plants previously treated with an aquaporin inhibitor or kept under nontreated conditions. The shoot was cut with a razor blade and the detached root, bathed in water, was carefully placed in the pressure chamber and sealed using silicon glue and polyvinylsiloxane (Coltene President, Switzerland) to prevent pressure leakage. Pressure was applied in the root medium at $0.1,0.2$ or $0.3 \mathrm{MPa}$, successively for $15 \mathrm{~min}$ each. The root exudate (xylem sap) was collected every $5 \mathrm{~min}$ at the cut surface using preweighed Eppendorf cones stuffed with tissue paper (Kimtech Science, Ontario, Canada). Sap collection was done three times at each pressure, and the next pressure was applied once a constant exudation rate was reached. The average value of the three exudation samples was normalized to root surface area, pressure and time. The root surface area was estimated by scanning with a Shimadzu scanner and analysed with Winrhizo software (Winrhizo, Regent, Canada).

\section{Statistical analysis}

In all experiments, transpiration data were normalized for the leaf area. For that, individual plant transpiration rate (TR, $\mathrm{mg} \cdot \mathrm{cm}^{-2} \mathrm{~min}^{-1}$ ) values were calculated by dividing transpiration values $\left(\mathrm{T}, \mathrm{mg} \cdot \mathrm{min}^{-1}\right.$ ) from the consecutive pot weighings, by leaf area $\left(\right.$ in $\mathrm{cm}^{2}$ ), measured at the end of each transpiration response experiment. Transpiration rate values were then normalized as described earlier (Kholová et al., 2010) to facilitate 
genotype and treatment comparisons. For the inhibition experiment, TR data were double normalized to the non-treated control; first by dividing individual TR data by mean TR of the control (TR ratio; TRR), then by dividing these TRR values by mean of TRR values before inhibitor treatment (Normalized TRR, NTRR), following earlier work (Sivasakthi et al., 2017; Tharanya et al., 2018). The NTRR data from inhibition of water transport pathways (cell-to-cell and apoplastic inhibition), transpiration rate response to increasing VPD data and root hydraulic conductivity data were analysed with the statistical package CoStat (version 6.204; Cohort Software, Monterey, CA, USA). One-way ANOVA was carried out to test for genotypic differences between treatments and genotypes. Means were compared using Tukey-Kramer test and LSD (at $P=0.05)$.

Two-way ANOVA was used to evaluate the effect of treatment and genotype, or genotype groups (conservative and profligate) and their interactions. For these analyses, the following data were used: (i) transpiration rate response to increasing VPD (Expt.1), replicated slope value data were used to test difference between slope value $>2 \mathrm{kPa}$ and $<2 \mathrm{kPa}$; (ii) the inhibition experiment used the replicated plant mean data of NTRR once stable transpiration was reached after inhibition; (iii) differences in canopy temperature data before and after inhibition; (iv) root hydraulic conductivity used normalized root exudate data after normalizing against root surface area, pressure and time $\left(\mathrm{mg} \cdot \mathrm{H}_{2} \mathrm{O} \cdot \mathrm{cm}^{-2} \mathrm{~min}^{-1} \mathrm{MPa}^{-1}\right)$ of both control and inhibited plants of each genotype and replicate. To fit data on transpiration rate response of each genotype to increasing VPD in the growth chamber, we applied a segmented linear regression (model $\mathrm{Y} 1=$ Slope $1 \times \mathrm{X}+$ Intercept 1 and $\mathrm{Y} 2=$ Slope $2 \times \mathrm{X}+$ Intercept2) or a linear regression (model $\mathrm{Y} 1=$ Slope $1 \times \mathrm{X}+$ Intercept 1 ); these algorithms fit the best model depending on the data, giving a $95 \%$ confidence interval, significance at $P>0.05$, and comparing slopes (Medina et al. 2019). This analysis was performed with Graph Pad Prism version 6 (Graph Pad Software, CA. USA).

\section{RESULTS}

Transpiration response to increasing VPD in the growth chamber

Upon VPD increase, TR increased in all tested genotypes, but the genotypes differed in the magnitude of TR response (rate of TR change). ICC 867 and ICC 14799 had a linear increase in TR with no restrictions throughout the whole range of tested VPD (Fig. 1), whereas ICC 4958 and ICC 8058 had TR restriction at VPD above $2 \mathrm{kPa}$, and then a decrease in transpiration beyond the transpiration breakpoint. VPD breakpoints of 2.53 and $2.69 \mathrm{kPa}$ were found for ICC 4958 and ICC 8058, respectively (Table 3, Fig. 1). Therefore, ICC 4958 and ICC 8058 had significantly lower TR than ICC 867 and ICC 14799 under high VPD conditions ( $>2 \mathrm{kPa}$ ) conditions (Fig. 1).

The slope values for ICC 4958 and ICC 8058 were 0.22 and $0.21 \mathrm{mg} \cdot \mathrm{cm}^{-2} \mathrm{~min}^{-1} \mathrm{kPa}^{-1}$ before the VPD breakpoints, and these were not significantly different from the slope values for ICC 14799.

\section{Transpiration response to aquaporin inhibitor treatment of whole plants with $\mathrm{H}_{2} \mathrm{O}_{2}$ or $\mathrm{HgCl}_{2}$}

Transpiration was measured for 3-4 h prior to applying the aquaporin inhibitors treatment to the roots and remained stable over time. In all genotypes, the pattern of aquaporin inhibition was similar: $\mathrm{H}_{2} \mathrm{O}_{2}$ had a consistently weak effect, followed by $100 \mu \mathrm{M} \mathrm{Hg}$, while $200 \mu \mathrm{M} \mathrm{Hg}$ uniformly had the strongest effect on the normalized transpiration rate ratio (NTRR) (Fig. S1). The analysis of NTRR response to treatment with $1 \mathrm{mM} \mathrm{H}_{2} \mathrm{O}_{2}$ revealed that, after $20 \mathrm{~min}$ of exposure to the inhibitor, NTRR decreased faster in the profligate genotypes (ICC 867 and ICC 14799) than in the conservative genotypes (ICC 4958 and ICC 8058) (Fig. 2A-C). The maximum inhibition occurred about $120 \mathrm{~min}$ after exposure to $\mathrm{H}_{2} \mathrm{O}_{2}$, with a NTRR decrease of profligate genotypes of $25 \%$ in ICC 867 and $30 \%$ in ICC 14799 (Fig. 2A; Fig. S1). In contrast, conservative genotypes showed a significantly lower decrease in transpiration, i.e. $8 \%$ in ICC 4958 and $15 \%$ in ICC 8058 (Fig. 2A; Fig. S1). After $120 \mathrm{~min}$ of exposure to $1 \mathrm{mM} \mathrm{H}_{2} \mathrm{O}_{2}$, NTRR recovered to nearly $100 \%$ in ICC 4958 and about $88 \%$ in ICC 8058 at about $270 \mathrm{~min}$ after treatment (Fig. 2A). Whether there could have been acclimation over time is not known and was not assessed here for the long term (i.e. several hours after treatment) in this experiment. The inhibition differences between genotypes was statistically significant at $P<0.01$ (Fig. S1).

Compared to $\mathrm{H}_{2} \mathrm{O}_{2}, \mathrm{HgCl}_{2}$ induced higher inhibition of NTRR in all tested genotypes (Fig. 2A-C). The NTRR decreased in a dose-dependent way, with a stabilization of the NTRR at about 90-120 min after exposure to the inhibitor (Fig. 2B,C; Fig. S1). With $100 \mu \mathrm{M} \mathrm{HgCl}_{2}$, NTRR decreased significantly more $(P<0.001)$ in the profligate than in the conservative genotypes (Fig. S1). In detail, NTRR decreased by about $60 \%$ in relation to transpiration of the untreated control (\% representing mean of stabilized data points) in ICC 867 and ICC 14799 (profligate) about $100 \mathrm{~min}$ after treatment. In

Table 3. Mean transpiration rate (over the whole VPD rang in Experiment 1), break point values (when significant) and slope values above and below $2 \mathrm{kPa}$ for transpiration rate (TR) in response to increasing VPD, assessed in four chickpea genotypes (ICC 4958 and ICC 8058 - conservative, ICC 867 and ICC 14799 - profligate) with contrasting TR response to VPD. Mean values ( $>2 \mathrm{kPa}$ and $<2 \mathrm{kPa}$ ) followed by different letters indicate significant differences with Tukey's test

\begin{tabular}{|c|c|c|c|c|c|c|c|}
\hline \multirow[b]{2}{*}{ genotype } & \multirow{2}{*}{$\begin{array}{l}\text { mean TR } \\
\mathrm{mg} \cdot \mathrm{H}_{2} \mathrm{O} \mathrm{cm} \mathrm{cm}^{-2} \mathrm{~min}^{-1}\end{array}$} & \multirow{2}{*}{$\begin{array}{l}\text { break point } \\
\mathrm{kPa}\end{array}$} & \multicolumn{2}{|l|}{ slope value $>2 \mathrm{kPa}$} & \multicolumn{2}{|l|}{ slope value $<2 \mathrm{kPa}$} & \multirow[b]{2}{*}{$R^{2}$} \\
\hline & & & $\mathrm{mg} \cdot \mathrm{H}_{2} \mathrm{O} \mathrm{cm}{ }^{-2} \mathrm{~min}^{-1}$ & SE & $\mathrm{mg} \cdot \mathrm{H}_{2} \mathrm{O} \mathrm{cm}{ }^{-2} \mathrm{~min}^{-1}$ & SE & \\
\hline ICC 4958 & 0.781 & 2.53 & $0.22 a$ & 0.01 & $-0.11 c$ & 0.01 & 0.77 \\
\hline ICC 8058 & 0.899 & 2.69 & $0.21 a$ & 0.01 & $-0.01 b$ & 0.04 & 0.80 \\
\hline ICC 14799 & 1.096 & No break point & $0.22 a$ & 0.01 & $0.21 a$ & 0.01 & 0.90 \\
\hline ICC 867 & 0.809 & No break point & $0.19 a$ & 0.003 & $0.20 \mathrm{a}$ & 0.01 & 0.90 \\
\hline
\end{tabular}


A

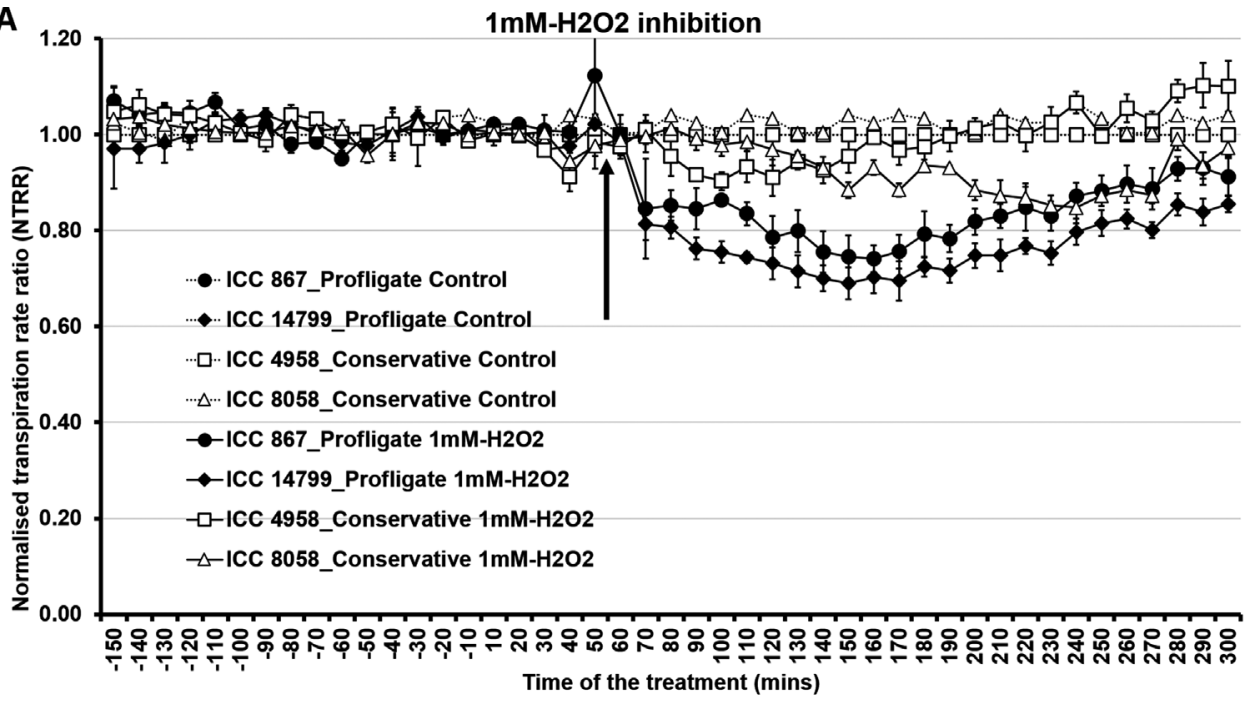

B

$100 \mu \mathrm{M}-\mathrm{HgCl} 2$ inhibition

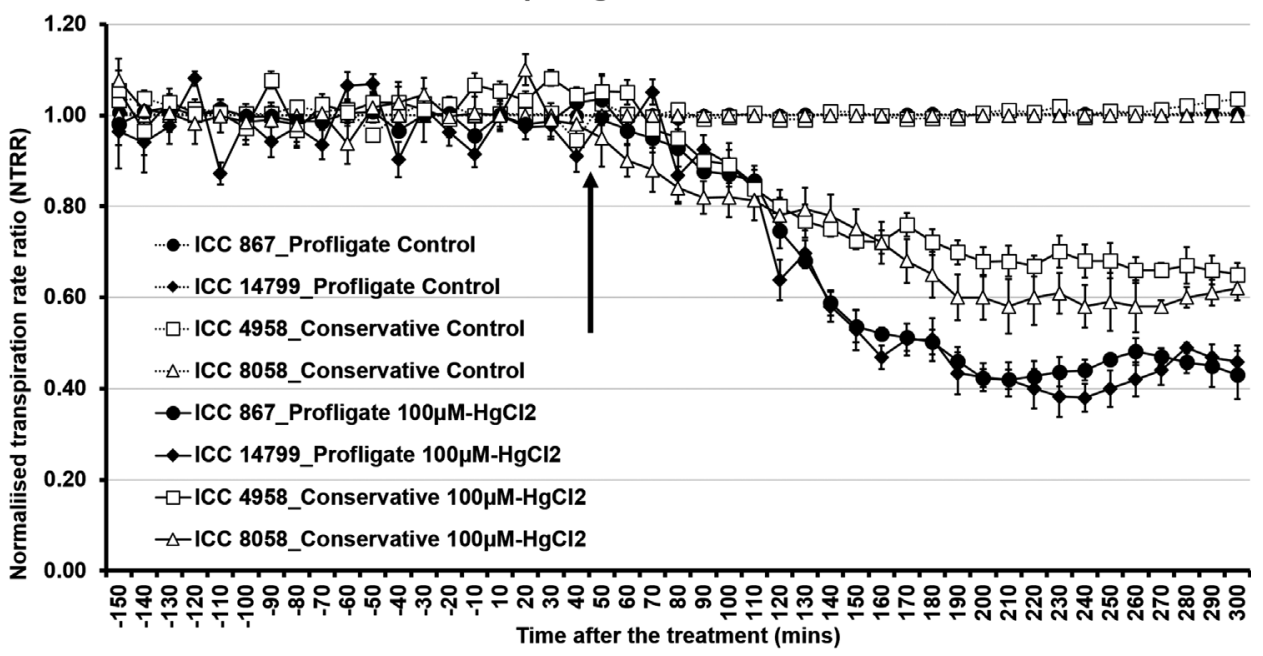

C

$200 \mu \mathrm{M}-\mathrm{HgCl} 2$ inhibition

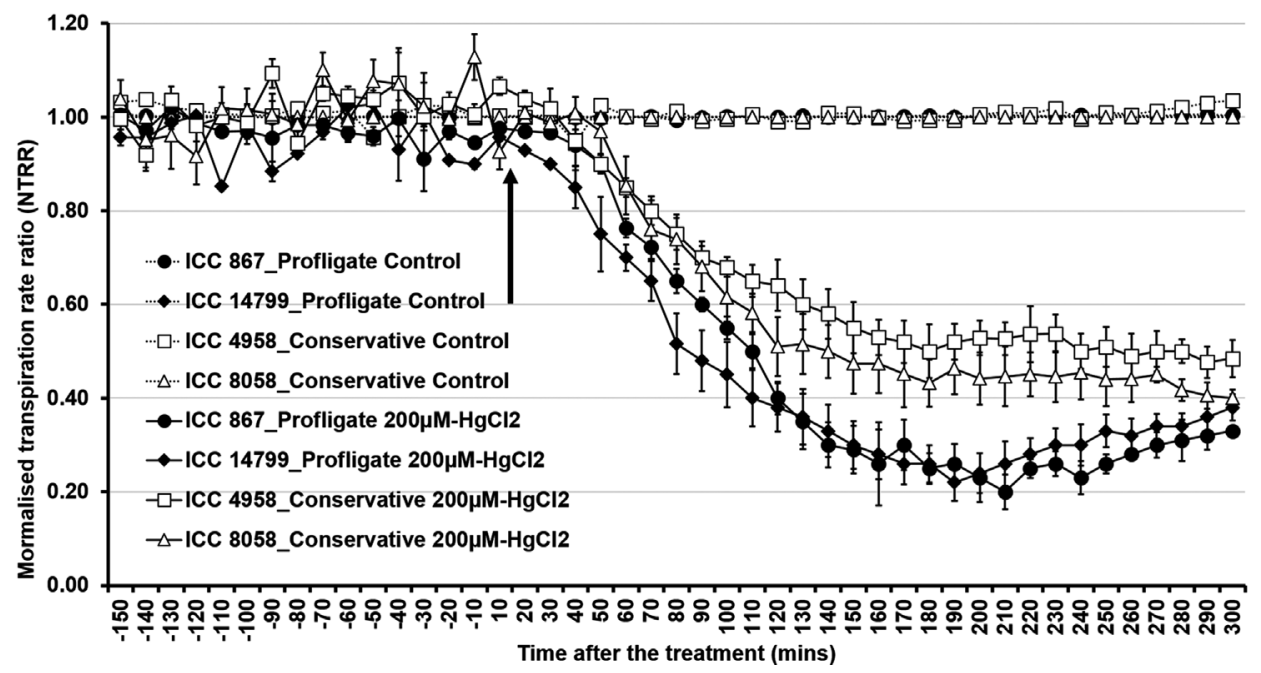

Fig. 2. Decline in normalized transpiration rate ratio (NTRR) upon aquaporin inhibitor treatment in four chickpea genotypes with contrasting transpiration response to high VPD: $1 \mathrm{~mm} \mathrm{H}_{2} \mathrm{O}_{2}$ (A), $100 \mu \mathrm{M} \mathrm{HgCl}$ (B), $200 \mu \mathrm{M} \mathrm{HgCl}$ (C). Genotypes ICC 867 and ICC 14799 are profligate (filled circle and filled diamond) and ICC 4958 and ICC 8058 are conservative (open square and open triangle). Plants were grown in hydroponics and tested at vegetative stage (26 days old). Each data point $(n=4)$ represents NTRR means \pm SE of four replicates per genotype per treatment. The arrow represents the time of application of treatment. 
contrast, in ICC 8058 and ICC 4958 (conservative) the NTRR reduction was about 25\% (Fig. S1). For the $200 \mu \mathrm{M} \mathrm{HgCl}_{2}$ treatment, the decrease in NTRR was more rapid than with $100 \mu \mathrm{M}$, particularly for the profligate genotypes ICC 867 and ICC 14799, and NTRR decreased significantly more $(P<0.001)$ in the profligate than in the conservative genotypes (Fig. S1). The $200 \mu \mathrm{M} \mathrm{HgCl}_{2}$ treatment led to a $65-70 \%$ reduction in transpiration measured at 60 to $150 \mathrm{~min}$ after $\mathrm{Hg}$ treatment in the profligate genotypes ((Fig. 2B,C; Fig. S1). In contrast, the conservative genotypes ICC 4958 and ICC 8058 only had a $40-45 \%$ NTRR reduction (Fig. S1).

Hydraulic conductivity of detached roots in response to the aquaporin inhibitor $\left(100 \mu \mathrm{M} \mathrm{HgCl}_{2}\right)$

Root hydraulic conductivity measurements were made over several days and each was at a different time of day. Figure S2 shows that morning root hydraulic conductivity was higher than midday root hydraulic conductivity, and hence replicates of the different genotypes were assessed at different times of day. In control conditions, the profligate genotypes (ICC 867 and ICC 14799) had significantly higher root hydraulic conductivity than the conservative genotypes (ICC 4958 and ICC 8058) $(P<0.01)$ (Fig. 3A).

The detached roots treated with $100 \mu \mathrm{M} \mathrm{HgCl}_{2}$ inhibitor showed a dramatic decrease in root hydraulic conductivity but there were no significant differences between the profligate and conservative genotypes after $\mathrm{HgCl}_{2}$ treatment (Fig. 3A). However, there was a significant interaction between the inhibitor effect and the category of genotype (profligate, conservative) (Table S2) in terms of the size of the decrease in root hydraulic conductivity following the treatment. Indeed, the profligate genotypes ICC 867 (83\%) and ICC 14799 (78\%) had a larger reduction in root hydraulic conductivity than the conservative genotypes (68\% in ICC 4958 and 70\% in ICC 8058) (Fig. 3B) $(P<0.05)$.

\section{Root anatomical differences}

After apoplastic inhibition, chickpea root anatomy was examined under a microscope to assess the presence of $\mathrm{Cu}_{2}[\mathrm{Fe}$ $(\mathrm{CN})_{6}$ ] precipitates. The chickpea root cylinder is composed of an epidermis consisting of elliptical cells surrounding a large cortex of ovoid parenchyma cells with intercellular spaces. The inner side of the cortex was delimited by an endodermis surrounding the vascular bundles (Fig. 4A). The endodermal cells were smaller than the cortical cells and were thickened on the inner tangential wall. The vascular bundles consisted of xylem (protoxylem and metaxylem vessels) in the centre and phloem at a peripheral position in the stele. Blockage of the apoplastic pathway with a combination of $\mathrm{K}_{4}\left[\mathrm{Fe}(\mathrm{CN})_{6}\right]$ and $\mathrm{CuSO}_{4}$ resulted in the whole root system appearing brown after treatment (Fig. 4B). The intercellular spaces also became progressively blocked with the insoluble crystals over time after treatment (Fig. 4C-E). In contrast, there was no sedimentation inside the cells.

Transpiration response to apoplast bypass flow inhibition with precipitates of $\mathrm{CuSO}_{4}$

Transpiration was measured at $3.1 \mathrm{kPa}$ (high VPD conditions) in all tested genotypes for almost $3 \mathrm{~h}$ prior to apoplast blockage treatment. Blockage of the apoplastic pathway (apoplastic pore) resulted in a rapid decrease in transpiration of all treated
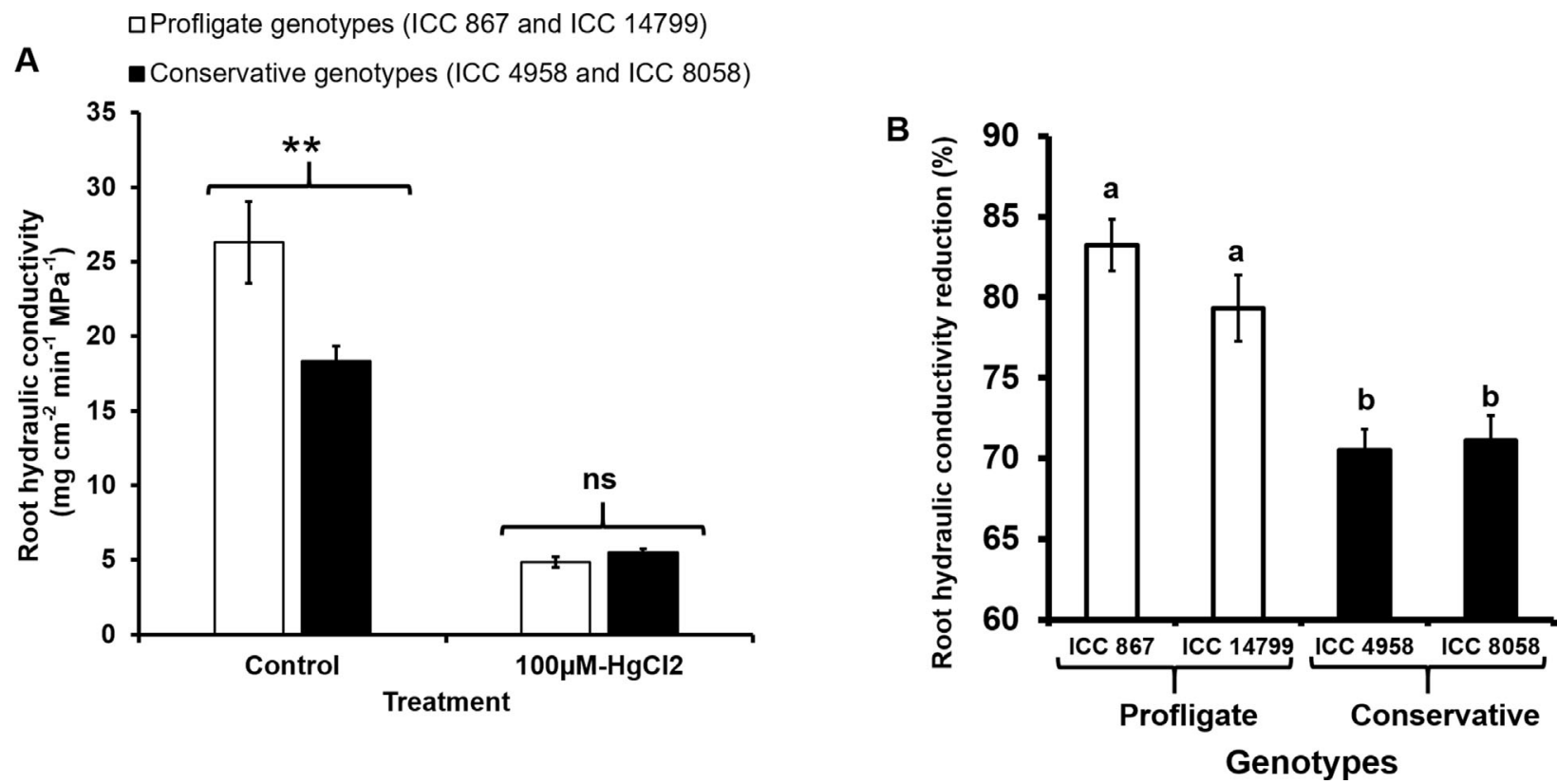

Fig. 3. Root hydraulic conductivity ( $\mathrm{mg} \cdot \mathrm{H}_{2} \mathrm{O} \cdot \mathrm{cm}^{-2} \mathrm{~min}^{-1} \mathrm{MPa}^{-1}$ ) of detached roots (A) and percentage (\%) inhibition of root hydraulic conductivity upon inhibitor treatment compared to controlled conditions (B). This was measured in four chickpea genotypes with contrasting plant transpiration response to VPD profligate genotypes (ICC 867 and ICC 14799) and conservative genotypes (ICC 4958 and ICC 8058) - after the application of an aquaporin inhibitor (100 $\mu \mathrm{M}$ $\mathrm{HgCl}_{2}$ ). ${ }^{* *} P<0.01$, ns no significant difference between conservative and profligate genotypes in both control and $100 \mu \mathrm{m} \mathrm{HgCl}_{2}$ conditions. Bars with different letters are significantly different $(P<0.05)$. 

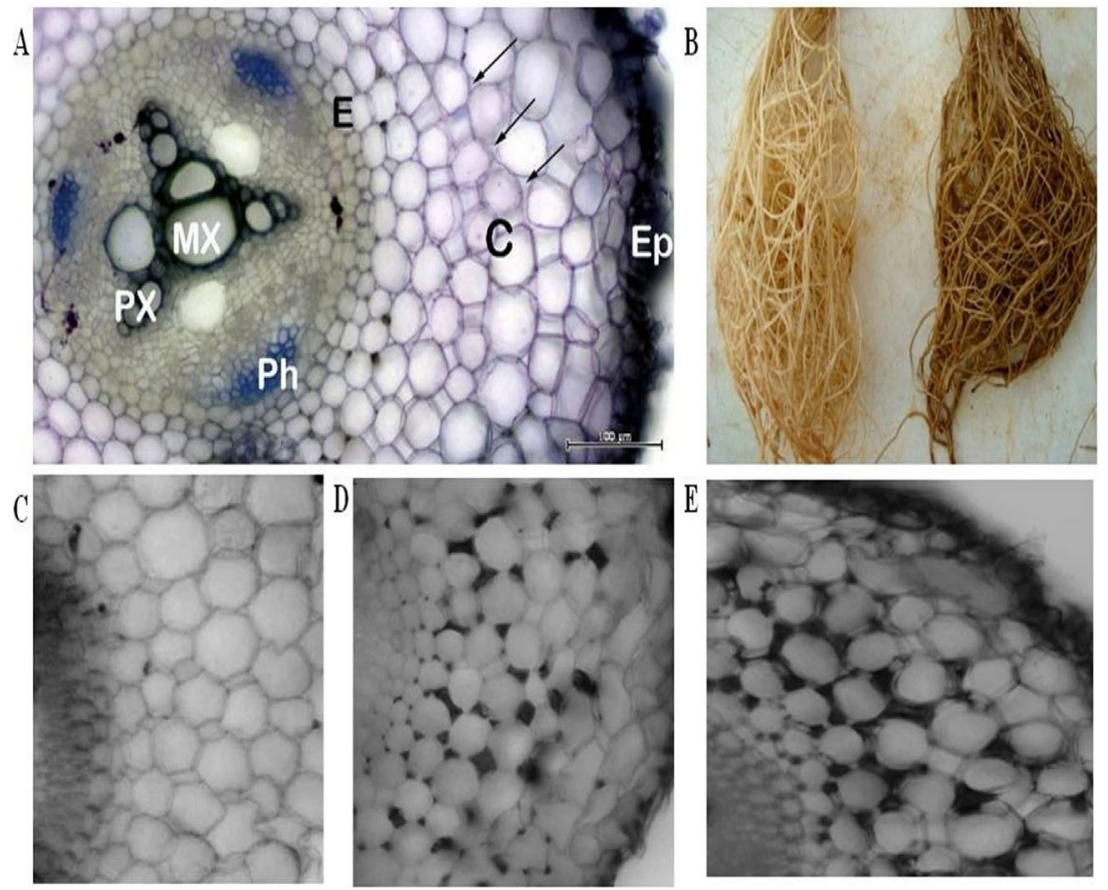

Fig. 4. Free-hand root cross-sections ( $A, C, D$ and $E$ ) and images (B) of chickpea after apoplast inhibition. Cross-section was made approximately 40 mm from root apex. Bars $=100 \mu \mathrm{m}$. (A) Over-view of root cylinder (epidermis - Ep, cortex - C, endodermis $-E$, phloem - Ph, protoxylem - PX, metaxylem - MX), with arrows to apoplastic pores. (B) Untreated (white, left) and treated (brown, right) chickpea roots after $3 \mathrm{~h}$ of apoplastic inhibition with CuSO ${ }_{4}$ in plants earlier treated with $1 \mathrm{~mm} \mathrm{~K}_{4}\left[\mathrm{Fe}(\mathrm{CN})_{6}\right]$. C, D and E represent evolution precipitation of $\mathrm{Cu}_{2}\left[\mathrm{Fe}(\mathrm{CN})_{6}\right]$ or $\mathrm{Cu}\left[\mathrm{CuFe}(\mathrm{CN})_{6}\right]$ crystals 0,1 and $3 \mathrm{~h}$ after $\mathrm{CuSO}{ }_{4}$ treatment.

plants about 20 min after $\mathrm{CuSO}_{4}$ application (Fig. 5). The NTRR following apoplastic blockage was slightly but significantly lower in the conservative $(40 \%)$ than in the profligate genotypes $(50 \%)(P<0.001)$, indicating that transpiration in conservative genotypes was more affected by apoplastic blockage than in profligate genotypes (Fig. S3).

\section{DISCUSSION}

Is restricted transpiration linked to the water transport pathway and root hydraulic conductivity?

The results of aquaporin-specific inhibition studies suggest that profligate chickpea genotypes depended more on the aquaporin-mediated water transport pathway than the conservative genotypes. These results are in agreement with similar results for other crop species, such as pearl millet (Tharanya et al., 2017), sorghum (Choudhary et al., 2013), wheat (Schoppach et al., 2014), soybean (Sadok \& Sinclair, 2010) and groundnut (Devi et al., 2012), where conservative genotypes suffered less aquaporin inhibition than profligate genotypes. Conversely, results of the apoplast blockage experiments suggest that the conservative genotypes were more dependent on the apoplastic pathway than the profligate genotypes under high VPD conditions. This result is well supported with earlier results for pearl millet apoplastic inhibition, which had a higher decline in transpiration following inhibition of the apoplastic pathway in conservative genotypes than in profligate genotypes (Tharanya et al., 2018). While there were clear differences in the water transport pathway between the conservative and profligate genotypes, the link between transport pathways and root hydraulic conductivity was such that the conservative genotypes had lower root hydraulic conductivity than the profligate genotypes. Additional studies are needed to confirm this link. Nevertheless, these results, together with an earlier report, suggest that genotypes, across several species, having conservative plant water use would mostly rely on the apoplastic pathway for water transport in the roots. This may represent an advantage under scenarios where water is limited and needs to be retained in the soil profile, as is the case in environments where chickpea is grown. However, this particular feature may be less advantageous in scenarios where water is abundant and would require adjustments to channel water flow, as used by the profligate genotypes because of their higher dependence on the cell-to-cell pathway for water transport. Our hypothesis, that genotypes differing in the TR response to high VPD would also differ in their water transport pathway, was confirmed here in our and previous results, and provides an opportunity to target these specific genotype behaviours into breeding for specific water availability scenarios.

\section{Is restricted transpiration under high VPD related to differences in plant vigour?}

Restricted transpiration under high VPD might be linked to high plant vigour (rapid early development of leaf area and aboveground biomass). Indeed, a larger canopy would, intuitively, require more water to support transpiration, which may limit in its capacity to channel water through the plant under high evaporative demand than genotypes with a smaller canopy area. Data from experiments described here and from other unpublished experiments (Table 1) showed that profligate 


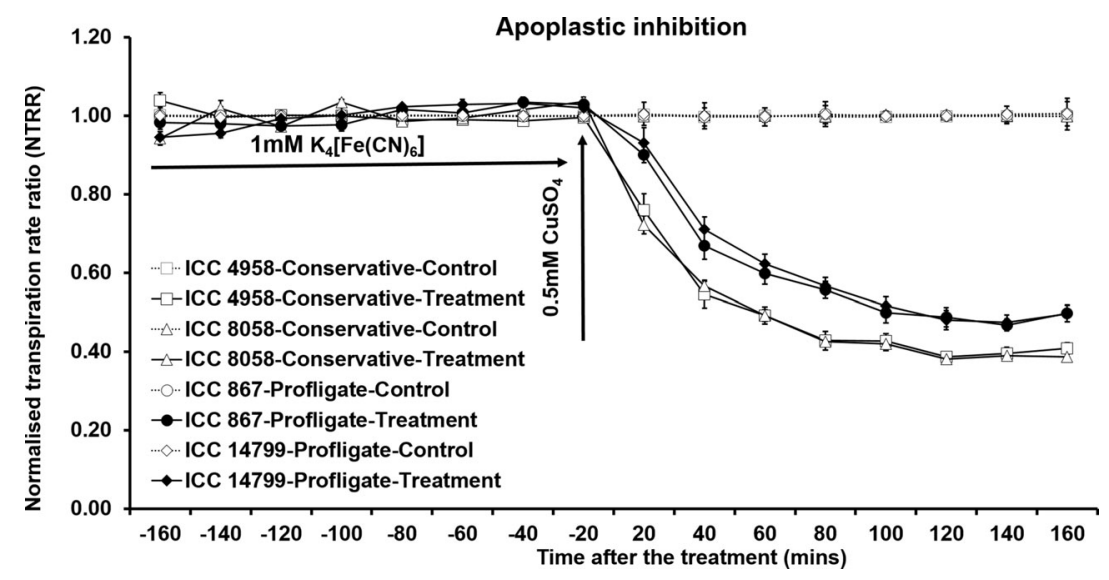

Fig. 5. Decline in normalized transpiration rate ratio (NTRR) following apoplast blockage, measured in four chickpea genotypes with contrasting transpiration response to VPD: ICC 867, ICC 14799 - profligate (filled circle and filled diamond) and ICC 4958, ICC 8058 - conservative (open square and open triangle). Each data point represents mean NTRR $\pm \mathrm{SE}$ of eight replicates per genotype. Apoplast pores were blocked by precipitation of $\mathrm{Cu} 2\left[\mathrm{Fe}(\mathrm{CN})_{6}\right]$ or $\mathrm{Cu}\left[\mathrm{CuFe}(\mathrm{CN})_{6}\right]_{\text {, }}$ following treatment with $\mathrm{CuSO}_{4}$ of plants treated earlier with $\mathrm{K}_{4}\left[\mathrm{Fe}(\mathrm{CN})_{6}\right]$. Plants were grown in hydroponics and tested at vegetative stage (26 days old).

genotypes had lower vigour, whereas conservative genotypes had higher vigour, confirming earlier findings (Zaman-allah et al., 2011a). Therefore, there appeared to be a link between the sensitivity of transpiration to increasing VPD and vigour. A similar interpretation was made in the case of pearl millet (Kholová et al., 2010), where the conservative genotype also had a larger canopy. These results are also consistent with others for recombinant inbred lines of chickpea and their parents, where the conservative behaviour under high VPD was also linked to high vigour (Sivasakthi et al., 2017). This link is important because, from a breeder's perspective, early vigour is an important trait for growth in water-limited environments (Richards, 2000; Botwright et al., 2002; Richards \& Lukacs, 2002), and here we show that the vigour trait may also be correlated with restricted transpiration, which would also lead to saving water. A question remains as to how high early vigour could be achieved in genotypes with conservative TR behaviour (and putatively restricted photosynthesis). Our interpretation is that these vigour differences occur early in the cropping cycle, when VPD is not high enough to trigger a restriction in transpiration. Early vigour may also contribute to higher yields because the shading of the soil surface by a large canopy would reduce incoming radiation and therefore limit evaporation from the soil, leaving more water available for the crop and increasing the crop's seasonal water use efficiency by as much as $25 \%$ (Siddique et al., 1990). Of course, early vigour would also mean a faster use of the water in the soil profile and a higher risk of exposure to terminal stress conditions, especially for late-flowering genotypes (Zaman-allah et al., 2011b). Further work is required to test the trade-offs between traits contributing to crop water use, i.e. canopy characteristics, transpiration restriction, or any advantage from soil shading with a large canopy.

What is the link between water pathways, early vigour and drought tolerance?

Genotype ICC 4958 was considered tolerant because it flowers early, whereas ICC 8058 was considered sensitive because of the relatively late flowering. Both ICC 867 and ICC 14799 were considered tolerant to terminal drought despite their relatively late flowering time (Krishnamurthy et al., 2010; Zaman-Allah et al., 2011b). The tolerance (ICC 4958, ICC 867 and ICC 14799) and sensitivity (ICC 8058) was shown to be a consequence of water saving mechanisms at an early stage, allowing these genotypes to retain more available soil water for the critical stages of reproduction and grain filling (Zaman-allah et al., 2011b). The sensitivity of ICC 8058 was seemingly related to its high early vigour combined with relatively late flowering and maturity, whereas the tolerance of ICC 4958 was a combination of early growth and water saving behaviour (and possible additional savings from lower soil water evaporation). These results suggest that water saving from restricted transpiration might be linked to a higher dependence on the apoplastic pathway for water transport in the root, which would only be beneficial for crops with specific phenology appropriate for a specific drought scenario. In other words, the water savings from restricted transpiration could not override the higher water demand of vigourous and late maturing genotypes like ICC 8058. In contrast, in genotypes that were less vigourous although profligate, like ICC 867 and ICC 14799 with low early vigour, even high transpiration under high VPD, putatively related to more dependence on the cell-to-cell water transport pathway, would be compensated by savings in water use. These interpretations reflects that fact that 'tolerance' to water stress is highly context-specific and follows a hierarchy of traits, where phenological duration, canopy development dynamics and capacity to restrict transpiration under high evaporative demand have important but interlinked roles. The role of stomatal control in this process is unclear. The above traits represent different scales of integration over time, with some traits changing within minutes (e.g. transpiration rate), while other traits are integrated over weeks (e.g. canopy development), thus one may interpret the role of stomata as being purely a response to the overall plant water balance.

\section{CONCLUSION}

In summary, a conservative transpiration response to increasing VPD was linked to a higher dependence on the apoplastic pathway for water transport and to high early vigour, whereas 
profligate transpiration under high VPD was related to stronger involvement of the cell-to-cell pathway for water transport, higher root hydraulic conductivity and lower early vigour. Based on the knowledge of genotype performance under terminal water stress, it appeared that drought tolerance could be explained as a combination of three traits: restricted transpiration under high VPD, vigour and early flowering, with a positive relationship between the first two traits. Given that early flowering is the only trait currently used in breeding of drought tolerance in chickpea, this work opens new opportunities to design improved cultivars on the basis of their trait relationships.

\section{CONFLICT OF INTERESTS}

The authors declare that they have no competing interests.

\section{ACKNOWLEDGEMENTS}

The authors acknowledge support from ICRISAT for a Blue Sky Research Project on 'Developing crops with high productivity at high temperatures', and the CGIAR Research Program (CRP) on Grain Legumes. The writing of this paper was supported by the Make Our Planet Great Again (MOPGA) ICARUS project (Improve Crops in Arid Regions and Future Climates) funded by the Agence Nationale de la Recherche (ANR, grant ANR-17-MPGA-0011). Special thanks to Mrs. Rekha Baddam and Mr. Mathew V. Joseph for help with statistical analysis and growth chamber operations.

\section{SUPPORTING INFORMATION}

Additional supporting information may be found online in the Supporting Information section at the end of the article.
Figure S1. Mean stabilized NTRR of profligate genotypes ICC 14799 and ICC 867 (filled bars) and conservative genotypes ICC 4958 and ICC 8058 (open bars) upon $1 \mathrm{mM} \mathrm{H}_{2} \mathrm{O}_{2}$ or 100 and $200 \mu \mathrm{M} \mathrm{HgCl}_{2}$ inhibition. Data $(\mathrm{n}=4)$ are mean values of stabilized NTRR after treatment. ${ }^{* *} P<0.01,{ }^{* *} P<0.001$ are significant differences for conservative and profligate genotypes.

Figure S2. Root exudation rate $\left(\mathrm{mg} \cdot \mathrm{H}_{2} \mathrm{O} \cdot \mathrm{cm}^{-2} \mathrm{~min}^{-1}\right)$ at different time points of four chickpea genotypes [ICC 4958, ICC 8058 (conservative) and ICC 867, ICC 14799 (profligate)]. Plants were grown in hydroponics and tested at vegetative stage (23 days old) using a pressure chamber. Root exudation was measured in detached roots at different time points (09:0010:00 h, dashed line and filled diamond; 12:00-14:00 h, dotted lines with filled circle; and 17:00-18:00 h, solid lines with filled square) (A). Each data points represent mean root exudation rate $( \pm \mathrm{SE})$ of five replicates per time points. (B) Slope of root exudation rate at specific time points: open bar 09:00-10:00 h, open bar with dashed lines 12:00-14:00 h, filled bar 17:00-18:00 h. Bars with different letters are significantly different $(P<0.05)$.

Figure S3. Mean stabilized NTTR values of profligate ICC 14799 and ICC 867 (filled bars) and conservative ICC 4958 and ICC 8058 (open bars) genotypes after apoplast blockage with $\mathrm{Cu}_{2}\left[\mathrm{Fe}(\mathrm{CN})_{6}\right]$ or $\mathrm{Cu}\left[\mathrm{CuFe}(\mathrm{CN})_{6}\right]$ crystals. Bars with different letters were significantly different $(P<0.05)$. ${ }^{\star * *} P<0.001$.

Table S1. Details of vapour pressure deficit (VPD) stress imposition inside the growth chamber.

Table S2. Means with standard error and two-way ANOVA, and one-way ANOVA, on the results of root hydraulic conductivity under control and $100 \mu \mathrm{M}-\mathrm{HgCl} 2$ inhibited conditions. Mean values followed by different alphabets indicate significant differences obtained through Tukey's test: L.S.D., Least significant difference.

\section{REFERENCES}

Aroca R.G., Amodeo S., Fernandez-Illesca S., Herman E.M., Chaumont F., Chrispeels M.J. (2005) The role of aquaporins and membrane damage in chilling and hydrogen peroxide induced changed in the hydraulic conductance of maize roots. Plant Physiology, 137, 341-353.

Belko N., Zaman-Allah M., Diop N., Cisse N., Zombre G., Ehlers J., Vadez V. (2013) Restriction of transpiration rate under high vapour pressure deficit and non-limiting water conditions is important for terminal drought tolerance in cowpea. Plant Biology, 15, 304-316.

Botwright T.L., Condon A.G., Rebetzke G.J., Richards R.A. (2002) Field evaluation of early vigor for genetic improvement of grain yield in wheat. Australian Journal of Agriculture Research, 53, 1137-1145.

Boursiac Y., Prak S., Boudet J., Postaire O., Luu D.T., Tournaire-Roux C., Santoni V., Maurel C. (2008) The response of Arabidopsis root water transport to a challenging environment implicates reactive oxygen species- and phosphorylation-dependent internalization of aquaporins. Plant Signaling and Behavior, 3, 1096-1098.

Choudhary S., Sinclair T.R., Vara Prasad P.V. (2013) Hydraulic conductance of intact plants of two contrasting sorghum lines, SC15 and SC1205. Functional Plant Biology, 40, 730-738.

Daniels M.J., Mirkov T.E., Chrispeels M.J. (1994) The plasma-membrane of Arabidopsis thaliana contains a mercury-insensitive aquaporin that is a homolog of the tonoplast water channel protein TIP. Plant Physiology, 106, 1325-1333.

Devi M.J., Sinclair T.R., Vadez V. (2010) Genotypic variation in peanut for transpiration response to vapor pressure deficit. Crop Science, 50, 191-196.

Devi M.J., Sadok W., Sinclair T.R. (2012) Transpiration response of de-rooted peanut plants to aquaporin inhibitors. Environmental and Experimental Botany, 78, 167-172.

Devi M.J., Sinclair T.R., Jain M., Gallo M. (2016) Leaf aquaporin transcript abundance in peanut genotypes diverging in expression of the limited-transpiration trait when subjected to differing vapor pressure deficits and aquaporin inhibitors. Physiologia Plantarum, 156, 387-396.

FAOSTAT. (2013) FAOSTAT database. Available at http://faostat3.fao.org/faostatgateway/go/to/down load/Q/QC/E (Accessed 3 June 2016).

Fletcher A.L., Sinclair T.R., Allen L.H. Jr (2007) Transpiration responses to vapor pressure deficit in wellwatered 'slow wilting' and commercial soybean. Environmental and Experimental Botany, 61, 45-151.

Fricke W., Chaumont F. (2006). Solute and water relations of growing leaf cells. In: Verbelen J.-P., Vissenberg K. (Eds) The Expanding Cell. Plant Cell Monographs, 5. Springer, Berlin, Germany, pp 7-32. Gholipoor M., Vara Prasad P.V., Mutava R.N., Sinclair T.R. (2010) Genetic variability of transpiration response to vapor pressure deficit among sorghum genotypes. Field Crops Research, 119, 85-90.
Gholipoor M., Choudhary S., Sinclair T.R., Messina C.D., Cooper M. (2013) Transpiration response of maize hybrids to atmospheric vapour pressure deficit. Journal of Agronomy and Crop Science, 199, 155160 .

Gilbert M.E., Holbrook N.M., Zwieniecki M.A., Sinclair T.R. (2011) Field confirmation of genetic variation in soybean transpiration response to vapor pressure deficit and photosynthetic compensation. Field Crops Research, 124, 85-92.

Hachez C., Moshelion M., Zelazny E., Cavez D., Chaumont F. (2006) Localization and quantification of plasma membrane aquaporin expression in maize primary root: a clue to understanding their role as cellular plumbers. Plant Molecular Biology, 62, 305-323.

Henzler T., Ye Q., Steudle E. (2004) Oxidative gating of water channels (aquaporins) in Chara by hydroxyl radicals. Plant, Cell and Environment, 27, 1184-1195.

Javot H., Maurel C. (2002) The role of aquaporins in root water uptake. Annals of Botany, 90, 301-313.

Katsuhara M., Hanba Y.T., Shiratake K., Maeshima M. (2008) Expanding roles of plant aquaporins in plasma membranes and cell organelles. Functional Plant Biology, 35, 1-14.

Kholová J., Hash C.T., Kumar P.L., Yadav R.S., Kocova M., Vadez V. (2010) Terminal drought-tolerant pearl millet [Pennisetum glaucum (L.) R. Br.] have high leaf $\mathrm{ABA}$ and limit transpiration at high vapour pressure deficit. Journal of Experimental Botany, 61, 1431-1440.

Kholová J., Murugesan T., Kaliamoorthy S., Malayee S., Baddam R., Hammer G.L., McLean G. 
Deshpande S., Hash C.T., Craufurd P.Q., Vadez V. (2014) Modelling the effect of plant water use traits on yield and stay-green expression in sorghum. Functional Plant Biology, 41, 1019-1034.

Kholová J., Zindy P., Malayee S., Baddam R., Murugesan T., Kaliamoorthy S., Hash C.T., Votrubová O., Soukup A., Kocová M., Niang M., Vadez V. (2016) Component traits of plant water use are modulated by vapour pressure deficit in pearl millet (Pennisetum glaucum (L.) R.Br.). Functional Plant Biology, 43, 423. https://doi.org/10.1071/FP15115

Krishnamurthy L., Kashiwagi J., Gaur P.M., Upadhyaya H.D., Vadez V. (2010) Sources of tolerance to terminal drought in the chickpea (Cicer arietinum L.) minicore germplasm. Field Crops Research, 119, 322-330.

Kumar J., Abbo S. (2001) Genetics of flowering time in chickpea and its bearing on productivity in the semi-arid environments. Advance in Agronomy, 72, 107-138.

Leport L., Turner N.C., French R.J., Barr M.D., Duda R., Daves S.L., Tennant D., Siddique K.H.M. (1999) Physiological responses of chickpea genotypes to terminal drought in a Mediterranean-type environment. European Journal of Agronomy, 11, 279-291.

Leport L., Turner N.C., Davies S.L., Siddique K.H.M. (2006) Variation in pod production and abortion among chickpea cultivars under terminal drought. European Journal of Agronomy, 24, 236-246.

Maggio A., Joly R.J. (1995) Effects of mercuric chloride on the hydraulic conductivity of tomato root systems. Evidence for a channel-mediated water pathway. Plant Physiology, 109, 331-335.

Maurel C. (2007) Plant aquaporins: novel functions and regulation properties. FEBS Letters, 581, 22272236.

Medina S., Vincente R., Nieto-Taladriz M.T., Aparicio N., Chairi F., Vergara-Diaz O., Araus J.L. (2019) The plant-transpiration response to Vapor Pressure Deficit (VPD) in Durum wheat is associated with differential yield performance and specific expression of genes involved in primary metabolism and water transport. Frontiers in Plant Science, 9, 1994. https://doi.org/10.3389/fpls.2018.01994

Messina C. D., Sinclair T. R., Hammer G. L., Curan D., Thompson J., Oler Z., Van Ooesteroom E., Gho C., Cooper M. (2013) Limited-transpiration trait may increase maize drought tolerance in the US Corn Belt. Agronomy Journal, 107, 1978 - 1986.

Miyamoto N., Steudle E., Hirasawa T., Lafitte R. (2001) Hydraulic conductivity of rice roots. Journal of Experimental Botany, 52, 1835-1846.

Niemietz C.M., Tyerman S.D. (2002) New potent inhibitors of aquaporins: silver and gold compounds inhibit aquaporins of plant and human origin. FEBS Letters, 531, 443-447.

Ranathunge K., Steudle E., Lafitte R. (2003) Control of water uptake by rice (Oryza sativa L.): role of the outer part of the root. Planta, 217, 193-205.

Ranathunge K., Kotula L., Steudle E., Lafitte R. (2004) Water permeability and reflection coefficient of the outer part of young rice roots are differently affected by closure of water channels (aquaporins) or blockage of apoplastic pores. Journal of Experimental Botany, 55, 433-447.

Ranathunge K., Steudle E., Lafitte R. (2005) Blockage of apoplastic bypass-flow of water in rice roots by insoluble salt precipitates analogous to a Pfeffer cell. Plant, Cell and Environment, 28, 121-133.

Richards R.A. (2000) Selectable traits to increase crop photosynthesis and yield of grain crops. Journal of Experimental Botany, 51, 447-458.

Richards R.A., Lukacs Z. (2002) Seedling vigor in wheat - sources of variation for genetic and agronomic improvement. Australian Journal of Agriculture Research, 53, 41-50.

Sadok W., Sinclair T.R. (2010) Transpiration response of 'slow-wilting' and commercial soybean (Glycine $\max ($ L.) Merr.) genotypes to three aquaporin inhibitors. Journal of Experimental Botany, 61, 821-829.

Schoppach R., Sadok W. (2012) Differential sensitivities of transpiration to evaporative demand and soil water deficit among wheat elite cultivars indicate different strategies for drought tolerance. Environmental and Experimental Botany, 84, 1-10.

Schoppach R., Wauthelet D., Jeanguenin L., Sadok W. (2014) Conservative water use under high evaporative demand associated with smaller root metaxylem and limited transmembrane water transport in wheat. Functional Plant Biology, 41, 257-269.

Siddique K.H.M., Tennant D., Perry M.W., Belford R.K. (1990) Water use and water use efficiency of old and modern wheat cultivars in a Mediterranean type environment. Australian Journal of Agriculture Research, 41, 431-447.

Sivasakthi K., Tharanya M., Kholová J., Wangari M.R., Thirunalasundari T., Vadez V. (2017) Chickpea genotypes contrasting for vigor and canopy conductance also differ in their dependence on different water transport pathways. Frontiers in Plant Science, 8, 1663. https://doi.org/10.3389/fpls.2017.01663

Steudle E. (1994) Water transport across roots. Plant and Soil, 167, 79-90.

Steudle E. (2000) Water uptake by roots: effects of water deficit. Journal of Experimental Botany, 51, 1531-1542.

Steudle E., Frensch J. (1996) Water transport in plants: Role of the apoplast. Plant and Soil, 187, 67-79.
Steudle E., Peterson C.A. (1998) How does water get through roots? Journal of Experimental Botany, 49, 775-788.

Tazawa M., Ohkuma E., Shibasaka M., Nakashima S. (1997) Mercurial-sensitive water transport in barley roots. Journal of Plant Research, 110, 435-442.

Tharanya M., Kholová J., Sivasakthi K., Thirunalasundari T., Vadez V. (2017) Pearl millet. In: Sinclair T. R. (ed.), Water-conservation traits to increase crop yields in water-deficit environments: case studies. Springer, Berlin, Germany, pp 73-83. https://doi. org/10.1007/978-3-319-56321-3-10

Tharanya M., Kholová J., Sivasakthi K., Seghal D., Hash C.T., Raj B., Srivastava R.K., Baddam R., Thirunalasundari T., Yadav R., Vadez V. (2018) Quantitative trait loci (QTLs) for water use and crop production traits co-locate with major QTL for tolerance to water deficit in a fine-mapping population of pearl millet (Pennisetum glaucum L. R. Br.). Theoretical and Applied Genetics, 131, 1509-1529.

Vadez V., Kholová J., Zaman-Allah M., Belko N. (2013a) Water: the most important 'molecular' component of water stress tolerance research. Functional Plant Biology, 40, 1310-1322.

Vadez V., Kholová J., Yadav R.S., Hash C.T. (2013b) Small temporal difference in water uptake among varieties of pearl millet (Pennisetum glaucum (L.) R.Br.) are critical for grain yield under terminal drought. Plant and Soil, 371, 447-462.

Vadez V., Kholová J., Medina S., Kakkera A., Anderberg H. (2014) Transpiration efficiency: new insights into an old story. Journal of Experimental Botany, 65, 6141-6153.

Yang Z., Sinclair T.R., Zhu M., Messina C.D., Cooper M., Hammer G.L. (2012) Temperature effect on transpiration response of maize plants to vapour pressure deficit. Environmental and Experimental Botany, 78, 157-162.

Ye Q., Steudle E. (2006) Oxidative gating of water channels (aquaporins) in corn roots. Plant, Cell and Environment, 29, 459-470.

Zaman-Allah M., Jenkinson D.M., Vadez V. (2011a) Chickpea genotypes contrasting for seed yield under terminal drought stress in the field differ for traits related to the control of water use. Functional Plant Biology, 38, 270-281.

Zaman-Allah M., Jenkinson D.M., Vadez V. (2011b) A conservative pattern of water use, rather than deep or profuse rooting, is critical for the terminal drought tolerance of chickpea. Journal of Experimental Botany, 62, 4239-4252.

Zhang W.H., Tyerman S.D. (1999) Inhibition of water channels by $\mathrm{HgCl} 2$ in intact wheat root cells. Plant Physiology, 120, 849-857.

\section{BLURB CONTENT}

Profligate genotypes depend more on the cell-to-cell pathway, which could relate to their higher root hydraulic conductivity, whereas conservative genotypes depend more on the apoplastic pathway which related to transpiration restriction under high VPD. 